\title{
In Defense of Academic Freedom and FaCUlty Governance: John Dewey, THE 100Th ANNIVERSARY OF THE AAUP, AND THE THREAT of CORPORATIZATION
}

\author{
Nicholas J. Eastman and Deron Boyles
}

\section{AbSTRACT}

This essay situates John Dewey in the context of the founding of the American Association of University Professors (AAUP) in 1915. We argue that the 1915 Declaration of Principles, together with World War I, provides contemporary academics important historical justification for rethinking academic freedom and faculty governance in light of neoliberalism and what we argue is an increased corporatization of higher education in the United States. By revisiting the founding of the AAUP and John Dewey's role in the various debates surrounding the establishment of the organization-including his broader role as a public intellectual confronted by war, questions of duty and freedom, and the shifting boundaries of the professoriate-we argue that professors today should demonstrate academic freedom and reclaim faculty governance for the public good over private interests.

\section{INTRODUCTION}

On the verge of the one hundredth anniversary of the founding of the American Association of University Professors (AAUP), we examine the organization's focus on academic freedom, shared governance, and the challenges the AAUP faced during its early years. The history is a fairly uncontested one: higher education in the late nineteenth and early twentieth centuries in the United States was the context for the struggle over academic freedom and shared governance. Dismissed professors, resignations by colleagues, and the struggle of professionalization characterize the period. ${ }^{1}$ A century later, we wonder about the state of academic freedom and shared governance. We argue that higher education is currently so influenced by corporatization and neoliberal entrepreneurialism that it is limiting the rights of professors, often with colleagues looking the other way or, worse, enacting administrative fiat 


\section{Nicholas J. Eastman and Deron Boyles}

under the pretense of faculty governance. We focus on the beginning of the AAUP and contemporary issues, not at the exclusion of the 1940 AAUP statement, the McCarthy era threats, the so-called "disruptions" of the 1960s and 1970s, and so on, but as a means of recapturing the significance of the origination of the AAUP and to challenge readers not to retreat from the intellectual courage that was so eloquently, though not unproblematically, articulated a hundred years ago.

\section{Historical CONSIDERATIONS}

The creation of the AAUP is a seminal event in the history of academic freedom because it marked the first time professors from across the United States came together to create a lasting interdisciplinary body dedicated to preserving the integrity of scholarship, teaching, and learning in higher education against intramural and extramural pressures, and sought to define for themselves what was acceptable academic speech. Leading up to the founding of the AAUP in 1915, as Robert Ludlum details, university professors-and university presidents-faced firings for a variety of reasons. Professors and administrators were dismissed for making claims that were incompatible with the religious institutions in which they were typically employed. In some instances, they stated controversial positions regarding social, political, and scientific issues (e.g., slavery, evolution); in other instances, they offended wealthy college benefactors with statements made in public speeches about graft and corruption. In still other instances, personality clashes within and among departments led to being fired. ${ }^{2}$

Prior to the AAUP, professors had little power over their own and their colleagues' tenure. Alexander Winchell was fired from Vanderbilt University in 1878 because of his scientific views on evolution. The University of Chicago dismissed Edward Bemis in 1895 because of his participation in events linked to the Pullman strike. Edward A. Ross was fired in 1900 from Stanford University for making claims against railroad companies, Chinese immigrants, and the gold standard. ${ }^{3}$ J. McKeen Cattell, a figure we will return to, was fired from Columbia in 1917 because of his opposition to World War I-after twenty-six years as a professor at Columbia. ${ }^{4}$ In each of these cases, colleagues protested, and some of them went so far as to resign. They did so in the face of a power structure that reinforced the centrality of boards of trustees and university presidents. According to Thorstein Veblen, university presidents, while not immune themselves from the pressures of boards of trustees, nonetheless exercised a virtual

plenary power of appointment, preferment, and removal, backed as this power is by a nearly indefeasible blacklist. So well is the academic blacklist understood, indeed, and so sensitive and trustworthy is the fearsome loyalty of the common run among academic men [sic], that very few among them will venture openly to say a good word for any one of their colleagues who may have fallen under the displeasure of some incumbent of executive office. ${ }^{5}$ 
When, as Daniel Pollitt and Jordan Kurland note, the first five cases were formally heard by the AAUP in 1915, they were only the latest in a long line brought by aggrieved faculty members and administrators. ${ }^{6}$

The first of the five cases was at the University of Utah, where seventeen faculty members, including the deans of the Law School and College of Arts and Sciences, resigned in protest over the firing of two faculty colleagues. ${ }^{7}$ Three other cases included Wesleyan University, University of Colorado, and University of Montana. Perhaps the most recognized of the first five cases, however, was the case of Scott Nearing at the University of Pennsylvania. Nearing was a popular economics professor who nonetheless irritated alumni and trustees with statements made off-campus. Upon his firing, 1,500 students and 60 faculty members signed a statement of protest but to no avail. ${ }^{8}$

Higher education around the turn of the twentieth century saw a significant transformation in academics in addition to new sources of funds and structures of governance. As new universities were built across the country, new intellectual ground was broken with the creation of new departments in the natural and social sciences, and inquiry and scholarship within these new fields, especially the social sciences, were not always palatable to those in power within and outside the universities. As Walter Metzger points out, "changes in the academic setting set off changes in the academic calling," and a far greater degree of intellectual diversity than had existed in the nineteenth-century's pious institutions of higher education accompanied the new diversity of academic disciplines. ${ }^{9}$ The AAUP's founding members understood that, in order to advance these disciplines for the good of the academic institution and the broader public, scholars needed the freedom to pursue the unconventional. Such pursuits, they realized, opened them up to attack from the very groups they saw as the beneficiaries of their inquiry: their institutions (specifically administrators) and the public. For this reason, the founders of the AAUP believed it necessary to outline the professor's function as a public intellectual. As the AAUP's founding president, John Dewey was in charge of appointing Committee A to investigate matters of academic freedom, and one of the AAUP's founder members and secretary, Arthur Lovejoy, played a leading role in investigating many of the cases brought in front of the organization during its first year. One result of Lovejoy's work was the creation of a document that would provide "a clear understanding of the principles which bear upon the matter," and which would lead to "the adoption by the universities of such arrangements and regulations as may effectually prevent any infringement of that freedom and deprive of plausibility all charges of such infringement." ${ }^{\prime 10}$ The 1915 Declaration of Principles (hereafter, 1915 Declaration) attempted to provide clarification for three facets of the job of the university professor: "freedom of inquiry and research; freedom of teaching within the university or college; and freedom of extra-mural utterance and action."11 
Although it sought to clarify the role of professor, the declaration crosses back and forth between professors' rights to express themselves "to students and to the general public, without fear or favor"12 and the requirement that the results of their inquiries "be set forth with dignity, courtesy, and temperateness of language."13 Students' confidence in their professors would be shaken if they felt that the professors were not expressing themselves "fully and frankly, or that college and university teachers in general are a repressed and intimidated class." ${ }^{14}$ The AAUP argued that if the professors were to fulfill their duties to their students and to the public, the university must remain "an intellectual experiment station, where new ideas may germinate and where their fruit, though still distasteful to the community as a whole, may be allowed to ripen" for the greater good of a free and democratic society. ${ }^{15}$

The AAUP argued that the responsibility of deciding which utterances achieved the proper balance of full and frank expression and temperateness of language should not be up to individual administrators or governing boards comprised of laypeople. Rather, as the AAUP laid out in its first practical proposal, the decision should be in the hands of "suitable judicial bodies, composed of members of the academic profession." ${ }^{16}$ The United States' entrance into World War I just a little over fifteen months after the AAUP formally adopted the 1915 Declaration would present a number of significant challenges to its ideal of self-governance and exert remarkable pressure on the matter of what counted as appropriate speech for university professors.

The war unfolded at a time in U.S. history when the influx of immigrants in the 1890s was joined by the expansion of the industrial revolution and social initiatives steeped in the rhetoric of democracy and progressivism. ${ }^{17}$ While the Civil War was fought without foreign intervention, the Spanish-American War of 1898 and the ensuing decision to annex the Philippines indicated to the world that the United States had the potential to expand beyond isolationist politics and become a player on the global stage. ${ }^{18}$ Above all, as Robert Wiebe points out, "the most powerful influence was a generalized sense of national crisis, one which millions predicated but could not define." ${ }^{19}$

Crisis brought about an intense form of jingoism. Citizens eagerly, if hegemonically, followed the dictates of an increasingly bureaucratized and specialized national government. Beyond volunteering for enlistment, parading in support of troops, buying bonds, and contributing to the Red Cross, there was a marked increase in the vilification of all things German and of anyone whose name appeared "foreign." Indeed, as Wiebe notes, Americans

answered the imperative yet misty questions about America's danger, they pointed to visible, available enemies, they played upon a host of incipient anxieties, and they satisfied the urge to violence. Only this exceptional appeal can account for the eagerness with which people made the most 
preposterous connections between foreign and domestic dangers; between the German menace and the Non-Partisan League, for example, or Bolshevism and the American Federation of Labor. ${ }^{20}$

Verging on paranoia, antiradicalism spread in such a way that unions, peace organizations, and antiwar magazines increasingly became targets for marginalization, if not extermination.

At the same time, the initial causes for which the AAUP was developed also altered because of the war. In advocating academic freedom, the AAUP had early committed itself to a position defending the rights of faculty members but found itself facing the wave of superpatriotism that attacked any organization that appeared to undermine a singular, nationalist identity. Questioning during war became unpatriotic or, worse, treasonous.

Initially, Dewey showed reluctant support for U.S. intervention in World War I, which he saw as having the potential to spread liberal democracy to the oppressed European masses. The modern world was too industrial, too mobile, and too interdependent to cling to the idea that isolation was a realistic possibility or that democracy was limited to national concerns. Issues of economic fairness and ethnic, racial, and cultural diversity were global in nature, and Woodrow Wilson's decision to go to war was not, according to Dewey's initial judgment, limited to protecting the economic interests of the American ruling class. The war was, according to Wilson's rhetoric, a war of democracy against autocracy and a war of freedom against oppression. As Robert Westbrook argues, "Dewey's support for American intervention in World War I was rooted less in pragmatic reason than in blind hope. ... In so doing, he fell victim to fuzziness of purpose, ideological idealization of an American mission, and uncritical adoption of inefficient, counterproductive technique." ${ }^{21}$ Dewey had, in 1915, considered Germany's ability to mobilize an entire country toward achieving its autocratic aims and worried that the dualistic tendencies Germany inherited from Immanuel Kant "bifurcated the German mind." 22 He initially thought the United States was justified in entering the war in order to overcome such dualistic thinking.

While a number of Dewey's fellow progressives shared in his optimism about the purpose and potential of the war, Randolph Bourne did not. Bourne's "A War Diary" and "Twilight of Idols," both published in the fall of 1917, let loose his contempt for Dewey and other pragmatists he saw "clinging wistfully to the belief that our war could get itself justified for an idealistic flavor, or at least for a worldrenovating social purpose," arguing that if Dewey and other pro-war progressives had not been swept up in the fervor of patriotism and had instead "turn[ed] their philosophy on themselves, they might have seen how thinly disguised a rationalization this was of their emotional undertow." ${ }^{23}$ Caught up in the idea that the Great War could spread democracy throughout Europe and be a war to end all wars, Dewey, according to Bourne, found himself in the unfamiliar territory of "values 
... subordinated to technique." ${ }^{24}$ Having been both Dewey's student and a strong admirer of his philosophy, Bourne felt abandoned by the pragmatists, whose philosophy, he believed, had its rightful place in transforming society through education rather than violence:

[A] rational nation would have chosen education as its national enterprise. .. But the nation did not use its isolation from the conflict to educate itself. It fretted for three years and then let war, not education, be chosen, at the almost unanimous behest of our intellectual class, from motives alien to our cultural needs, and for political ends alien to the happiness of the individual.... What concerns us here is the relative ease with which the pragmatist intellectuals, with Professor Dewey at the head, have moved out their philosophy, bag and baggage, from education to war. ${ }^{25}$

Bourne argued that Dewey and other pragmatists who supported U.S. intervention were disastrously naïve about the possibility of directing the country's patriotism and educational and civic institutions toward peace and pluralistic democracy instead of victory and rabid nationalism. Whether Bourne's own pacifist commitments prevented him from taking full account of the political realities of the conflict or the consequences of American neutrality, and a potential German victory, is up for debate. Nonetheless, Bourne's critique of Dewey's optimism regarding the war remains relevant. As Alan Cywar argues, "the vital question respecting Dewey's philosophy becomes not how it failed to keep American progressives out of the war, but how it did not succeed in bringing the conflict to a better conclusion. ${ }^{.26}$ In this respect, Dewey's assessment of the necessity of military force might well have been accurate, but this does not change the fact that he had underappreciated the power of nationalistic and capitalistic interests to direct American intervention toward different purposes through propaganda. Indeed, Dewey ultimately abandoned the idea that military force could serve as an instrument for democracy. Writing in 1923 , Dewey admitted that "the war created an illusion of real unity to which many fell victims, myself among the number."27

The educational fallout of what Bourne had called the "war-technique" came quite close to home for Dewey when Nicholas Murray Butler, the president of Columbia University, designated himself the judge, jury, and executioner of the career of any professor testing the boundaries of academic freedom regarding the war. Whereas the 1915 Declaration had called for faculty associations to be in charge of self-governance and self-discipline in matters of academic freedom, Butler contended, "What had been tolerated before becomes intolerable now. What had been wrongheadedness was now sedition. What had been folly was now treason," and for any person who "acts, speaks, or writes treason," according to Butler's definition thereof, "the separation of such a person from Columbia will be as speedy as the discovery of his offense." ${ }^{28}$ Butler dismissed two Columbia 
professors, James McKeen Cattell and Henry Wadsworth Longfellow Dana, for what he considered treasonous acts. In Cattell's case, treason amounted to writing a letter to Congress in support of a bill that would send only voluntary forces to fight in Europe. For Dana, participating in the radical-pacifist People's Council and advocating that students protest the proposed Conscription Act qualified as sedition and grounds for termination. Butler bypassed the faculty committee, on which Dewey sat, that had been formed to investigate matters of academic freedom. Dewey resigned from the committee in protest but remained at Columbia. The pendulum of academic freedom had swung decidedly away from the rights of professors expressing themselves fully and frankly toward their duties to exercise caution and temperateness of language.

Extreme caution and deference to patriotism is on full display in the AAUP's "Report of the Committee on Academic Freedom in Wartime," which was produced by a special subcommittee of the General Committee on Academic Freedom and Tenure. The subcommittee, also led by Lovejoy, found that the 1915 Declaration was written and ratified during a time of peace and that it was now necessary to reinterpret these principles in a time of war. Lovejoy took great pains to shore up the patriotic credibility of American universities, boasting that they had done more than any other institution to fill the ranks of the military and that it had been their "supreme pride to have trained a body of youth, who in this time of testing of our national fibre [sic], have with the rarest exceptions manifested a splendid and selfdevoting loyalty to the cause of their country." ${ }^{29}$ Whereas the American university in 1915 had been an "inviolable refuge" from the "tyranny of public opinion," ${ }^{30}$ it now listed its direct and indirect influence on public opinion among its other contributions to the war effort.

Once the professoriate's patriotic credentials are established, the report moves on to the matter of treason, warning that the heightened tension during a time of war often leads to the charge of treason being equivalent to its proof. ${ }^{31}$ The report concedes that clear acts of treason should be handled by governmental authorities, but it maintains that the public statements and acts of a citizen who is also a university professor should remain matters of academic freedom and, as such, should be adjudicated by a faculty committee per the 1915 Declaration. The report addresses the case of Cattell not to comment on whether his acts as a citizen were treasonous but as an example of what occurs when the authority of deciding such a matter was inappropriately taken out of the hands of a faculty committee.

The report makes four detailed recommendations for how the university should approach academic freedom during times of war. While the third and fourth sections argue that professors cannot be forced into voluntary war efforts or be dismissed solely due to German or Austro-Hungarian ancestry, the first two deal directly with matters of freedom of speech and obedience to law. The first states that those convicted of breaking the law should be immediately dismissed from the 
university, while those who are under indictment should be temporarily suspended from their university duties until a formal verdict is reached. Regarding conscientious objectors, the report recommends the matter be left to the courts without "supplementary disciplinary actions" from the college or university-as long as it is established by a faculty committee that the professor has refrained from distributing propaganda or proselytizing both within and outside the university walls. ${ }^{32}$

The report takes up propaganda, specifically as it relates to matters of conscription, in its second point of clarification on academic freedom during war. Disseminating propaganda for the purpose of causing others to resist lawful forced military service is, the committee argues, grounds for immediate dismissal, as it directly promotes disobeying the law. However, since the declaration of war is a congressional power, opposition to the war becomes opposition to the law:

Before war is declared, it is any citizen's right to oppose such a declaration; while the war is going on, it is his right to express his opinion as to the terms upon which peace is to be concluded, and as to the wisdom or efficacy of proposed measures and instrumentalities for the proposed conduct of war; but it is not his right between the declaration of war and the conclusion of peace to obstruct or impede the execution of any measure lawfully determined upon as requisite for the safety of the country and the successful prosecution of the war. ${ }^{33}$

According to the report's subsequent examples, statements about the categorical immorality of war qualify as openly hostile to the government's lawful war efforts, and while they may be permissible (if also distasteful) during peacetime, they are "manifest incitement to disaffection and public disorder" during wartime. ${ }^{34}$

Although he never directly addressed Bourne's criticisms, Dewey came to see the power war propaganda had to incite destructive nationalism and smother possibilities for intelligence to guide policies toward a lasting peace. While even after the war he maintained that American intervention was necessary in order to prevent a German victory that would have proved disastrous for Europe and the United States, he was humbled by the degree to which his own dispassionate clarity of thought had been vulnerable to the strong current of nationalist sentiment:

The ideals of the United States have been defeated in the settlement because we took into the war our sentimentalism, our attachment to moral sentiments as efficacious powers, our pious optimism as to the inevitable victory of the 'right,' our childish belief that physical energy can do the work that only intelligence can do, our evangelical hypocrisy that morals and 'ideals' have a self-propelling and self-executing capacity. ${ }^{35}$

After the war, Dewey had little hope that the Treaty of Versailles or the League of Nations could lead to a lasting peace, and to that end, he joined his friend Salmon Levinson in his "Outlawry" effort to start a movement to make war illegal. ${ }^{36}$ Both 
Levinson and Dewey came to see the League of Nations as an instrument of future wars rather than an impediment to them. Early in 1917, Dewey had hoped that the war would unite people across the world through democratic partnerships. The League, however, was a partnership of aristocratic governments, the very same governments whose national interests had fueled the war. In other words, democratic ideology had indeed spread, but it was of the top-down, managerial variety concerned more with securing markets for industry and circulating capital than sustaining a bottom-up movement for international human rights. The result of the war, according to Dewey, was the consolidation of power instead of its diffusion. While these consolidated powers might pay lip service to war as a last resort or a defensive measure, these were the same hollow justifications those in power had always used in the prosecution of unjust wars. Dewey's new hope was that outlawing war would force other, more democratic methods of diplomacy. ${ }^{37}$

Lovejoy criticized Dewey's opposition to the League as well as his desire to outlaw war, seeing Dewey's stance as one that was too uncompromising and impractical to address the political realities of the modern world. Considering that Lovejoy's report on academic freedom during wartime equated vocal and public opposition to the government's legal declaration of war with stirring up public unrest and inappropriate agitation, Dewey's contention that war should be outlawed was, in fact, a practical perspective that sought to preserve democratic diversity of opinion against oppressive political orthodoxy.

Dewey's disagreement with Lovejoy continued into the mid-1920s when the AAUP, the American Association of Colleges (AAC), the American Association of Universities (AAU), and a number of other organizations of higher education met to revisit and amend the 1915 Declaration. Only the AAUP and the AAC, which was more conservative and represented the interests of college presidents, adopted the proposed changes to the 1915 Declaration. The result of this partnership was the 1925 Statement of Principles, which borrows heavily from the 1915 document regarding what constitutes academic freedom and the rules of tenure. The most noticeable difference between the two documents is that the latter jettisons the lengthy philosophical justifications of its tenets in favor of a concise series of paragraphs-four regarding academic freedom and four addressing tenure-that fit on less than three pages.

What was added is, perhaps, more important than what was cut. ${ }^{38}$ The writers of the 1915 Declaration did not wish to enumerate grounds for dismissal, preferring instead to leave those decisions to each institution's faculty committees; however, they did list "grave moral delinquency" as an exception to the recommended threemonth notice of dismissal prior to the end of the academic year. The 1925 document calls for similar oversight of dismissals by faculty committees working in tandem with the governing board of the university. "Exceptions to this rule," the document notes, "may be necessary in cases of gross immorality or treason when the facts are 
admitted. In such cases summary dismissal would naturally ensue." ${ }^{39}$ Upon reading that charges of treason had been added as grounds for immediate dismissal, Dewey wrote to Lovejoy and H. W. Tyler, who had chaired the conference, expressing his concern that the wording placed charges of treason in the court of public opinion instead of law, since, if a member of a university faculty was convicted of treason in a court of law, there need be no further investigation or measures taken by the university. Further, relying on a popular interpretation of the views of individual administrators or governing boards to define treason allowed for abuse of power. Charges of treason, Dewey argued, "might be employed in cases similar to those arising during the late war to justify the dismissal of teachers whose views on national policy were contrary to the patriotic sentiments of the time. ${ }^{30}$ Cattell's and Dana's careers, as well as Dewey's own frustration at having his committee bypassed by Butler, were clearly still fresh in his mind, as was, perhaps, his regret at having been among those too easily persuaded by arguments for U.S. involvement in the war. Tyler reasoned that leaving the word out risked losing the support of the conservative AAC, and his tepid response that the word "would probably do no real harm" was anything but convincing. ${ }^{41}$ While Tyler was motivated by naïve appeasement, Metzger argues that Lovejoy "still needed more time to recuperate from the illness of superpatriotism. ${ }^{\text {"42 }}$ His response to Dewey's concern that the word treason might be used prejudicially was that there had been a gentleman's agreement that it be understood in the legal sense. If it were used to silence dissent, Lovejoy argued, the professor would be in a position to sue for damages. It is difficult to see how the possibility of compensation is the same as adequate defense of academic freedom - unless we update the context and reevaluate academic freedom in light of the corporatized university.

\section{Bridging the AAUP's IdeA of ACADEMIC FreEdom With Contemporary Issues in Higher Education}

The cry for academic freedom in American universities originated from the early European scholars' cry for the freedom to philosophize, or libertas philosophandi, and especially from the German professors' variation of such freedom, particularly their notion of freedom of inquiry characterized by the term lehrfreiheit. ${ }^{43}$ The American version of academic freedom was first explicitly given expression in the 1915 Declaration's treatment of the key facets of academic life: freedom of inquiry and research; freedom of teaching; and freedom of extramural utterance and action. The authors posited these freedoms as being in the public's interest, since boards of trustees, as the legal authority of their institutions, were actually entrusted by the state with providing a crucial service to the public, and trustees could not legitimately assume this public trust without granting professors the freedoms necessary to accomplish the latter's own public duty: to serve society with 
the knowledge they produce. Metzger points out that by framing higher education as a public trust and the professors' freedom of inquiry as a public service, the authors of the 1915 Declaration got around the fact that in the United States, unlike in Germany, higher education took place in private as well as public institutions. ${ }^{44}$

Metzger also argues that the American notions of academic freedom as expressed in the 1915 Declaration were unlike the German notions granting freedoms to the professor, the student, and even the institution itself; in America, academic freedom came to stand for the freedom of the academic. It did not stand, Metzger argues, for the freedom of the student to learn or for the institution in general, except in cases where a threat to the autonomy of the institution bore directly on the academic (e.g., when states required loyalty oaths of their employees after World War II). Metzger explains that the primary concern of the 1915 Declaration was with what happened in a university, not with what happened to a university. ${ }^{45}$ Metzger's reading appears to be correct, but only in the most superficial sense. Academics are institutional beings, and in being granted rights, it is for the institution itself that those rights are granted, since academics act on its behalf when they act as academics. This is true even when it means that the institution's own actions will be constrained. To authorize the academic to act is to authorize the institution to act, since they are in a mutually constitutive relationship with each other. The 1915 Declaration recognizes this distinction in its call for university professors to be understood as appointees of the university instead of its employees: "University teachers should be understood to be, with respect to the conclusions reached and expressed by them, no more subject to the control of the trustees, than are judges subject to the control of the President, with respect to their decisions." ${ }^{.66}$ The academic exists because the institution exists, and the institution exists because the academic exists, each being the other's raison d'être. Thus, what happens to the university also happens in the university, since neither the university nor its academic exists without the other.

The 1940 Statement of Principles on Academic Freedom and Tenure, the definitive understanding of the AAUP's stance on academic freedom, while imposing some responsibilities on the academic, also accepted the premises of the 1915 Declaration, namely, that the primary concerns of the academic are inquiry and research, teaching, and extramural activities; that the institution assumes a public trust; and that academic freedom is exercised in service of the public, stating that the "free search for truth and its free exposition" is the basis for "the common good." ${ }^{37}$ To have received the almost universal acceptance that it has, however, meant that the 1940 Statement had to be more nuanced in elaborating upon these freedoms than was the 1915 Declaration. Thus, while professors should enjoy freedom of inquiry, they also should be honest in conducting research; while professors should have the freedom to teach their courses, they should stick to matters within their expertise; and while professors, also being citizens of the larger public, should be 
able to express issues important to them, they should be careful to dissociate themselves from their institutions when doing so. ${ }^{48}$

Nevertheless, the core premises of the 1915 Declaration were assumed by the latter Statement. The first premise is that academic institutions assume a public trust, so that the professors' activities are public services, that is, they serve the common good. Whether this remains a valid premise or not hinges on the existence of something "public" that is separate, distinct, and perhaps in opposition to something "private." The second premise is that the primary activities of the professors (inquiry, teaching, and extramural utterances) require the freedom to perform them, since they are public services.

\section{The Corporate University as a Public Trust}

As we have already stated, the AAUP's founders had ample reason to be concerned about private industry's ability to influence the primary activities of the academic. They sought to shield professors at both private and public universities from administrators and boards of trustees acting on behalf of private industry by arguing that the trustees of any educational institution that appeals to the public for support are necessarily trustees for the public rather than their private benefactors. The 1915 Declaration posits that "any university which lays restrictions upon the intellectual freedom of its professors proclaims itself a proprietary institution, and should be so described whenever it makes a general appeal for funds; and the public should be advised that the institution has no claim whatever to general support or regard." ${ }^{.49}$ At the core of this statement are the beliefs that education is fundamentally different from job training and that higher learning at the university was, and should always remain, indissoluble from freedom of inquiry and teaching for the public's benefit. This is so because any effort to streamline or standardize academic practices to conform to the university's governing economic interests or ideology is anathema to how higher learning functions as a public service in a democratic society. The founders of the AAUP understood education to be a public service, even when that education takes place at a private university. A university, public or private, whose primary function was workforce training is not, on their view, an educational institution but rather a proprietary one.

What, then, do we make of our current institutions of higher education? Despite the prevalence of references to public service in university mission statements, we argue that the idea that the university today actually functions as a public trust is highly questionable. With the drastic reduction of public funding to colleges and universities, corporate-sponsored research and grant activity is increasing markedly. The steady erosion of the public sector and communitarianism, and its replacement by neoliberal ideologies favoring privatization and individualism, have resulted in a profound transformation of the purpose of the university. Far from being exclusively or even primarily a site for free and open inquiry in the pursuit 
of truth for the public good, the university, especially since the 1970s, functions instead as a publicly subsidized servant of transnational corporations that provides a skilled workforce and, more importantly, proprietary research and development, with emphasis most recently in the areas of science, technology, engineering, and mathematics (STEM). We wonder if it would not be better to have the platitudes of public service taken from university mission statements and replaced with a list of corporate sponsors. Better yet, the corporations could display their brands alongside school insignia in keeping with the 1915 Declaration's stance that proprietary institutions "should not be permitted to sail under false colors." ${ }^{50}$

In what ways, then, do universities differ from private corporations? Slaughter and Rhoades argue that, while the goal of academic capitalism may be to generate greater amounts of private wealth for corporations, privatization is not the aim of the corporate university itself, since it would then lose its privileges as a nonprofit institution. Instead, the corporate university is able to receive continued publicsector support while preserving its access to private markets. As neoliberal policies place greater restrictions on public funds, however, universities have more of an incentive to raise tuition and seek corporate partnerships. ${ }^{51}$ By dissolving the boundary between public concerns and private gains, academic capitalism "entails a redefinition of public space and of appropriate activity in that space," ${ }^{52}$ where appropriate activity is defined as that which aligns with and promotes capitalist models of growth, both for the university (in enrollment, endowment, and continued grant funding) and its corporate sponsors (as return on investment in terms of financial and human resources).

This redefinition is most apparent in the extent to which higher education (like K-12 education) has adopted the language and logic of the marketplace. Students and the public more generally are now understood to be "clients," "constituents," and "customers," and maximizing return on investment dictates that educational outcomes be quantifiable rather than qualitative. Colleges and universities are now being asked to document not only graduation rates and time-to-completion data, but the rate of employment of graduates and their corresponding salaries. ${ }^{53}$ Such accounting discourse inevitably favors profitability and employability over other concerns such as criticality, social justice, or deliberative democracy-since the former produce more reliable sources of data while reinforcing rather than challenging commercial interests. The requirement that educational success and excellence be measured in order to be understood has led to an explosion in administrative hiring that seeks to execute the closely related corporate functions of brand management and quality control that, at best, have little to do with free inquiry and the quality of teaching and learning and, at worst, are counterproductive to these aims as public services.

On the brand management or marketing side, resources that might otherwise be utilized for academic purposes such as library acquisitions, funding scholarship 
unlikely to receive grant subsidies, supporting graduate students, and hiring new full-time, tenure-track faculty are diverted to services and facilities that appeal to students as consumers. Online courses proliferate on the logic of convenience. Multimillion-dollar recreational and athletic facilities become integral in recruiting undergraduate students, and nonacademic buildings such as student centers (sometimes paradoxically called student unions) are mini-malls in which transnational corporations such as fast food and beverage chains and booksellers gain access to their target market without the students needing to leave campus.

It is no surprise that the dramatic rise in full-time university administrative and management positions that handle the corporate consultants, expenditures, licensing, and revenue streams associated with student living (as opposed to student learning) has been accompanied by an overreliance on non-tenure-track instructors, who now shoulder the responsibility of most college instruction. The AAUP argues that "[n]on-tenure-track positions of all types now account for 76 percent of all instructional staff appointments in American higher education" and that this trend reflects a shift in priorities rather than an economic necessity since "the greatest growth in contingent appointments [has] occurred during times of economic prosperity. ${ }^{\prime 54}$ It is certainly the case that universities today are altogether more inclusive demographically than they were even a few decades ago and that this has made some of the new administrative and student support positions justified. Adding administrative positions in student services, however, does not validate the loss of academic support and mentoring that students experience when many of their undergraduate courses are vulnerable to the high turnover rate that comes with employing contingent faculty. The chilling effect that this corporate restructuring has on the primary domains of academic freedom as addressed in the 1915 Declaration (inquiry, teaching, and extramural speech) is a topic we will return to, but, for now, it provides sufficient evidence that, while the corporate university may well serve multiple interests, it does not serve them equally.

When profitability and competitive rankings are the administration's top priorities, "quality control" becomes a matter of streamlining and standardizing services according to a factory model that minimizes costs and maximizes output. Online course offerings increase and departments that fail to meet their numbers are either shuttered or repurposed to support those that do (e.g., foreign language departments offering more courses in international business). Students, who through escalating tuition and fees have come to bear much of the burden of the state's declining support of higher education, are under tremendous economic pressure to leave college, credentials in hand, as quickly as possible in order to avoid crippling debt. Time to degree and job placement statistics have become the primary means by which university administrators market the quality of their institutions to prospective students (and their families) looking to secure a place for themselves in an increasingly precarious job market. Equating quality and efficiency, however, 
points to a fundamental misunderstanding of the very commodity the university is in a unique position to offer: an intellectual experience. We agree with Raphael Sassower that the increasing failure of corporate university administrators to fully invest in and support their faculty and libraries and prioritize pedagogy over the university's countless other services amounts to a significant lapse in quality control and, as such, is a failure of the very logic that governs academic capitalism. As Sassower contends,

But even if university administrators were better corporate managers or leaders, they would still fail to admit the most important distinguishing factors that set the academy apart from other institutions of contemporary culture. Academic institutions should be devoted to harboring intellectual rebels and fermenting dissent from the debilitating effects of power and authority, may it be church, state, or industry. As such, they should be offering a sanctuary of sorts. ${ }^{55}$

Of course, such a sanctuary is open to fewer and fewer professors (and by extension, their students) with each new concession to the demands of profitability and efficiency. Adjuncts and other part-time instructors who lack tenure invariably experience the pressure to self-censor in light of their expendability. Even the tenured and long-term non-tenure-track professors are increasingly vulnerable to the demands that academic capitalism and the consumer culture of higher education place on free inquiry, teaching, and extramural speech.

\section{The Primary Activities of the Academic}

\section{Freedom of Inquiry}

Despite (or perhaps because of) the tremendous growth the university has experienced over the last century, the fundamental concerns of Dewey and the AAUP's founders are as critical today as they were during the early decades of the twentieth century. Dewey's 1902 essay “Academic Freedom" shows his great concern that money, "indispensable as a means," holds the power to override the educational purposes of the university. "If the university is to be a true university," he warns, "money and all things connected therewith must be subordinate. But the pressure to get the means is tending to make it an end; and this is academic materialismthe worst foe of freedom of work in its widest sense." ${ }^{56}$ Although the founders of the AAUP recognized and addressed the threats material interests posed to the free pursuit of knowledge for the public good in the 1915 Declaration, an undercurrent of optimism that such threats were in decline tempers their sense of caution. Indeed, the AAUP's 1940 Statement acknowledges that pecuniary gain could be detrimental to academic freedom, but so entrenched was the idea that disinterested (as opposed to proprietary) research was the primary function of academic inquiry that 
the authors of the Statement assumed that pecuniary motivation was an anomaly that could be kept in check by the requirement that the researcher(s) disclose such motivations. This stands in stark contrast to the prevailing attitude of those who wield the greatest power in shaping academic inquiry today: university administrators, policy makers, and corporate officials. Unwilling to continue with traditional models of academic funding that support disinterested research, universities, in concert with state and federal entities, have turned to promoting the interests of global capital over the public good, making academics into entrepreneurs whose careers depend on their ability to secure funding from sources outside of the university. As competition for state and federal grants intensifies due to their increasing scarcity, academics turn to corporate sponsors to underwrite their careers.

In March 2014, Carole Vance and Kim Hopper, two longtime scholars in Columbia University's Mailman School of Public Health, were fired for failing to secure the required 80 percent of their salaries through grant funding. ${ }^{57}$ Vance and Hopper, who both held non-tenure-track appointments but had been at Columbia for 27 and 26 years respectively, are leaders in their fields. Vance's work explores the various and often contentious ways that human sexuality intersects with human rights and matters of public policy and health. Recently, she has focused her scholarship on sex trafficking and the potential ethnographic research holds for informing public policy. Hopper's research examines historical and current practices of psychiatric care and issues pertaining to homelessness. He is the past president of the National Coalition for the Homeless and has spent three decades as an advocate for the rights of the homeless. Both scholars are politically engaged public intellectuals whose work within and outside of the academy has been in service to society's most vulnerable populations and who have provided important critiques of domestic as well as international policies affecting those populations. Mailman's policy that professors become entrepreneurs who fund 80 percent of their own salaries, a policy that pertains to both tenure and nontenure-track appointments, functions as a de facto and detached form of censorship that channels inquiry toward whatever holds the greatest grant-getting potential. Under such a regime, academic prospecting consumes a considerable portion of the scholar's time, especially for non-tenure-track researchers who can no longer rely on their public service or even reputable academic publications to guarantee employment. Having secured much of their own funding, scholars must devote a large percentage of their working hours meeting the conditions of their grants (80 percent for National Institutes of Health grants). ${ }^{58}$ This leaves academics with little remaining time to pursue other lines of inquiry or forms of public service, such as teaching or mentoring, both of which were widely recognized points of excellence for Hopper and Vance. Prioritizing grants above all other academic endeavors confirms Dewey's fears that funding would become the end rather than the means of academic life. 
Of course, not all departments are equally subjected to the grants culture. That professors in the humanities are not usually required to secure their own sources of funding, however, has less to do with the fact that inquiry in these fields enjoys greater protection than the social, natural, or computer sciences and more to do with the fact that it is simply less valuable to corporate interests. Although this may seem like a blessing, it comes at the price of being viewed as a set of disciplines for which the doors are kept open and the lights kept on through the beneficent subsidies of the money-making disciplines. These subsidies come with pressure to limit costs by reducing the number of tenure-track positions and graduate funding available. Inquiry in these fields is, therefore, not shaped by the restrictions and demands of the grant culture but through the reduction in the number of positions that support critical scholarly inquiry.

Freedom of Teaching

The demands that the grant culture places on the academic's time is not the only means by which corporate culture imposes on teaching at the university. As we have previously stated, managerial priorities of efficiency and profitability have placed an increasing share of undergraduate teaching in the hands of contingent faculty who provide the university with a labor source that is inexpensive and expendable and, as such, not likely to enact academic freedom to challenge the status quo. Further, the overreliance on contingent faculty for classroom teaching reduces the number of tenured positions available, which weakens faculty governance and concentrates power in administrative positions. Classroom teaching is one of the primary ways the academic engages with the public as well as the means by which the corporate university distinguishes itself from other corporations and justifies its appeals for public funds. In light of this role, a model of higher education in which most teaching is carried out by those who are utterly without job security can hardly be expected to "help make public opinion more self-critical and more circumspect," which the AAUP's founders argued were characteristic functions of the university in a democratic society. ${ }^{59}$

The same neoliberal economic pressures that have left the bulk of undergraduate teaching to contingent faculty and weakened the tenured faculty's control over teaching have also led to sharp rises in tuition, reinforcing the trend of viewing university attendees as consumers rather than students. This superficial characterization has come with equally superficial appeals to their rights (as paying customers). Self-styled university “watchdog” groups like Campus Reform or David Horowitz's Students for Academic Freedom have provided platforms for attacks on tenure disguised as student advocacy. ${ }^{60}$ Calling on universities to respect the students" "right" to a "balanced" curriculum, these groups argue that tenure is not so much a measure protecting academic freedom as it is a useful tool for protecting liberal indoctrination. It is no surprise that the targets of these crusades 


\section{Nicholas J. Eastman and Deron Boyles}

for a balanced curriculum are most often professors in the humanities and social sciences, fields in which interrogations of the relationship between knowledge and power and critiques of exploitative and discriminatory policies and social practices are common. Dewey recognized that such threats to academic freedom were not spread equally across departments when he argued that, "Political economy, sociology, historical interpretation, psychology in its various possible applications, deal face-to-face with problems of life.... Hence the right and duty of academic freedom are even greater here than elsewhere." ${ }^{\text {"1 }}$ Absent are calls from Horowitz and other advocates of tenure reform for business schools to provide coverage of Marxism in their lectures and course materials to achieve a balanced curriculum. Instead, by targeting those in the humanities and social sciences, the "watchdog" groups both misrepresent university teaching as whole and undermine what remains of the critical function of the university. These groups have the power to shape university teaching without ever stepping inside the classroom. The eagerness with which they have disseminated students' selective smartphone recordings as proof that universities are sites of leftist indoctrination facilitates not greater transparency and accountability, as advertised, but classrooms that stifle critical discourse and privilege the view that knowledge claims are always politically neutral and objective. ${ }^{62}$

While such unwanted exposure in the media has caused some universities to take measures against unauthorized recording in classrooms, it has also resulted in brand-conscious administrators managing instruction by suppressing potentially controversial or unconventional classroom practices, as was the case for Patricia Adler, a longtime tenured professor of sociology at the University of Colorado at Boulder. Adler's teaching came under close scrutiny because of a skit about prostitution she coordinated for her class "Deviance in U.S. Society." The skit involved undergraduate teaching assistants volunteering to act as prostitutes from different social classes. The assistants studied their roles and developed scripts in order to answer questions from their classmates about their lifestyles, what led them to prostitution, and how their exposure to risks such as arrest, physical violence, and contracting HIV varies according to their social status. Adler had taught the course and used the skit for many years without complaint until the fall semester of 2013, when a former teaching assistant raised concern that the skit might be offensive. Adler claims that Steven Leigh, dean of the College of Arts and Sciences, informed her the skit was too risky in the "post-Penn State environment." ${ }^{63}$ Since there is no obvious link between Jerry Sandusky's criminal sexual abuse of children and adult undergraduate students volunteering to illustrate social stratification by pretending to be prostitutes, we infer that Leigh's comment indicates the potential damage to his prominent university's brand. ${ }^{64}$

This case illustrates the degree to which potential threats to the university's brand can supersede threats to academic freedom, even for tenured professors. The 
result is a culture of silence that, as William Tierney and Vicente Lechuga argue, "occurs not only by attempts to fire a professor when he or she speaks out" but can be "pervasive to such an extent that individuals do not even consider speaking out." ${ }^{\prime 65}$ It is for this reason that the 1915 Declaration argued that classroom discourse should be understood as a privileged form of communication "often designed to provoke opposition or arouse debate" and is "not to be supposed to be utterances for the public at large." ${ }^{\prime 66}$ Combating the corrosive effects of a culture of silence and restoring the privileged status of classroom speech can only come through renewed support for the protections of tenure and faculty governance. It is no longer possible for the few who currently hold tenure to remain passive spectators of the assault on academic freedom in higher education. Their tenured status has done little or nothing to prevent the transfer of three-quarters of undergraduate teaching to unprotected contingent faculty, nor has it given them the power to stem the rise of neoliberal managers who either directly suppress practices they see as potential controversies and threats to public relations or simply replace the freedom to teach with a checklist of standard practices conforming to a logic of accountability. Our position is not that professors should not be held responsible for the quality of their teaching or that a certain amount of incompetence is a reasonable price to pay for academic freedom. Rather, we contend that standardizing instruction degrades the quality of teaching instead of protecting it. Moreover, if we are correct that one's professional peers are the best judges of competent instruction, then strengthening faculty governance and increasing the number of tenure-track instructors are the best measures against incompetent teaching.

\section{Freedom of Extramural Speech}

Just as the primary activities of the academic share overlapping concerns, so too do the threats to academic freedom posed by cultural hegemony, corporate management styles, and neoliberalism generally. Having profoundly shaped and imposed limits upon freedom of inquiry and teaching at the university, the two activities most directly associated with the work of the academic, there is little reason to believe extramural speech would be safe from the same limitations. The 1915 Declaration is ambivalent about how to balance the rights of professors as citizens and their responsibilities to their profession. On the one hand, the document maintains that academics do not forfeit their right to support "organized movements which they believe to be in the public interest," yet it qualifies this position with its stance that professors should "avoid hasty or unverified or exaggerated statements" as well as "intemperate or sensational modes of expression" when doing so. ${ }^{67}$ What counts as intemperate or sensational is open to broad interpretation, and any speech that counters dominant ideologies, no matter how politely phrased, could easily be labeled as such by any administrator looking to purge the faculty of dissenters, just as Butler did during World War I with Cattell 
and Dana. ${ }^{68}$ Extramural speech deemed sufficiently patriotic and supportive of the war efforts was, of course, unquestioned. The speech of those who swam with the current was, therefore, afforded a privileged status. Currently, tenure protects the extramural speech of professors from all political persuasions, provided that speech is not indicative of incompetence or unfitness for teaching and research at the university. But with tenure increasingly wedded to grant funding and grant funding reliant on transnational corporations, the privileged few with protected speech become less likely to be those who question the tenets of global capitalism or the role the university plays in promoting those tenets. Put differently, if the academic capitalists and entrepreneurs are the only ones whose extramural speech is protected, there is little possibility that the university could retain a critical function for the larger public.

Much like Randolph Bourne's criticism that Dewey and many other intellectuals had lost their way during the World War I to such a degree that, "Their thought becomes little more than a description and justification of what is going on," we argue that there is a parallel today with the university as an instrument of neoliberalism. ${ }^{69}$ Whereas the universities of 100 years ago endeavored to show their usefulness to the war's effort to spread democracy throughout the world, today's educational institutions seek to make themselves vital to the interests of global capital. Restructuring academic work to align with the efficiency, productivity and profitability of transnational corporations has proved antithetical to academic freedom. Academic capitalism redirects inquiry toward proprietary interests, relegates teaching to an exploited and expendable workforce, and protects only the speech of those who share its values. Without a renewed understanding that upholding academic freedom and tenure is an ethical obligation of the professoriate, there is little hope that the university can be much beyond a factory for producing patented knowledge and skilled workers for other corporations. If the university is to be of service to a public good, assuming that such a concept is possible and distinguishable from private goods, it is incumbent on the faculty to secure and defend a space of freedom in which a diversity of truth and knowledge claims can be debated and discussed under the name higher education.

\section{Notes}

1. As Hans-Joerg Tiede persuasively argues, the rise of newspapers and journalistic coverage of faculty firings are partly responsible for the public even knowing about the issue of academic freedom and university governance. See Hans-Joerg Tiede, “'To Make Collective Action Possible': The Founding of the AAUP," Journal of Academic Freedom 5 (2014): 1-29. Available at http://www.aaup.org/reports-publications/journal-academic-freedom /volume-5-2014/\%E2\%80\%98-make-collective-action-possible\%E2\%80\%99. Accessed September 27, 2014.

2. Robert P. Ludlum, "Academic Freedom and Tenure: A History", The Antioch Review 10, no. 1 (Spring 1950): 3-34.

\section{E\&C Education and Culture}


3. For more on Ross, see Warren J. Samuels, “The Firing of E. A. Ross from Stanford University: Injustice Compounded by Deception?” The Journal of Economic Education 22, no. 2 (Spring 1991): 183-90.

4. See William Summerscales, Affirmation and Dissent: Columbia's Response to the Crisis of World War I (New York: Teachers College Press, 1970).

5. Thorstein Veblen, The Higher Learning in America (New York: B. W. Huebsch, 1918), 252.

6. Daniel H. Pollitt and Jordan E. Kurland, "Entering the Academic Freedom Arena Running: The AAUP's First Year," Academe 84, no. 4 (July-August, 1998): 45-52. As the authors' introduction reveals, Arthur O. Lovejoy (who would become a seminal figure in the move toward codifying academic freedom) resigned his position at Stanford University, with six other professors, over the firing of Edward Ross in 1901, well before the first formal cases were heard. For a glimpse into some of the earlier instances of academic freedom, see William G. Tierney and Vicente M. Lechuga, "Academic Freedom in the 21st Century”, Thought \& Action (Fall 2005): 7-22, 8-9. For the full account of the first five official cases, see Walter P. Metzger, ed., Professors on Guard: The First AAUP Investigations (New York: Arno Press, 1977).

7. Indeed, Lovejoy borrowed money from John Dewey in order to travel by train to investigate at Utah. This is important, if not interesting, because the AAUP had not yet formalized the funding and practices of on-site investigation. See Pollitt and Kurland, 48.

8. Pollitt and Kurland, 51.

9. Walter P. Metzger, "Origins of the Association: An Anniversary Address," AAUP Bulletin, no. 3 (June 1965): 230.

10. AAUP, "Academic Freedom," Bulletin of the American Association of University Professors 29, no. 1 (February 1943): 82-101, 82.

11. Ibid., 83 .

12. Ibid., 87.

13. Ibid., 94 .

14. Ibid., 90.

15. Ibid., 93.

16. Ibid., 99.

17. For a recent interpretation of the First World War, see Christopher Clark, The Sleepwalkers: How Europe Went to War in 1914 (New York: HarperCollins, 2012).

18. See, for instance, David M. Kennedy, Over Here: The First World War and American Society (Oxford: Oxford University Press, 1980/2004), 376-81.

19. Robert H. Wiebe, The Search for Order, 1877-1920 (New York: Hill and Wang, 1967), 286.

20. Ibid., 287. For a more recent account that indicates a much stronger German threat during this period of time, see Howard Blum, Dark Invasion: 1915: Germany's Secret War and the Hunt for the First Terrorist Cell in America (New York: HarperCollins, 2014).

21. Robert B. Westbrook, John Dewey and American Democracy, (Ithaca: Cornell UP, 1991), 202-3.

22. Jay Martin, The Education of John Dewey: A Biography (New York: Columbia University Press, 2002), 267. See also, John Dewey, German Philosophy and Politics (New York: Henry Holt, 1915); and John Dewey, "Our Educational Ideal in Wartime” (1916), MW 10: 178-82.

23. Randolph Bourne, "A War Diary" in The Radical Will: Randolph Bourne (Selected Writings: 1911-1918), ed. Olaf Hansen (New York: Urizen Books, 1977): 321-22.

24. Randolph Bourne, “Twilight of Idols," 343. 
25. Ibid., 338-39.

26. Alan Cywar, "John Dewey in World War I: Patriotism and International Progressivism," American Quarterly 21, no. 3 (1969): 580. See also Lynda Stone, “Dewey’s Contribution to an American Hubris: Philosophy of Democracy, Education, and War." Philosophy of Education (Urbana: Philosophy of Education Society, 2003): 274-81; and Jim Garrison, "Recovery, Reconstruction, and Self-Renewal," Philosophy of Education (Urbana: Philosophy of Education Society, 2003): 282-84.

27. John Dewey, "Political Combination of Legal Cooperation" (1923), MW 15: 106. For more on how Dewey mistook international relations, see Molly Cochran, "Dewey as International Thinker," in Molly Cochran, ed., The Cambridge Companion to Dewey (Cambridge: Cambridge University Press, 2010): 309-36. See also, Alan Ryan, John Dewey and the High Tide of American Liberalism (New York: W. W. Norton, 1995): 154-99; and Daniel Levine, "Randolph Bourne, John Dewey, and the Legacy of Liberalism," The Antioch Review 29, no. 2 (Summer 1969): 234-44.

28. Quoted in Carol Signer Gruber, "Academic Freedom at Columbia University, 19171918: The Case of James McKeen Cattell," AAUP Bulletin 58, no. 3 (September 1972): 302.

29. Arthur O. Lovejoy, Edward Capps, and A. A. Young, "Report of Committee on Academic Freedom in Wartime," Bulletin of the American Association of University Professors (1915-1955) 4, no. 2/3 (February-March 1918): 30. Accessed on August 20, 2014, http:// www.jstor.org/stable/40216871.

30. AAUP, “Academic Freedom," 93.

31. Lovejoy, "Report of Committee on Academic Freedom in Wartime," 31.

32. Ibid., 36-37.

33. Ibid., 38. In light of current events relating to ISIS and Al Qaeda, we wonder how war is understood given that no congressional declaration has yet been made. Would Ward Churchill or Sam Al-Arian, for example, be treated differently if their objections and accusations were considered under the aegis of a nondeclared war?

34. Ibid.

35. John Dewey, “The Discrediting of Idealism," The New Republic 20, no. 257 (1919): $285-86$.

36. See Charles F. Howlett, "John Dewey and the Crusade to Outlaw War," World Affairs 138, no. 4 (Spring 1976): 336-355.

37. See Westbrook, John Dewey and American Democracy, 263-65.

38. See Walter P. Metzger, "The 1940 Statement of Principles on Academic Freedom and Tenure," Law and Contemporary Problems 53, no. 3, "Freedom and Tenure in the Academy: The Fiftieth Anniversary of the 1940 Statement of Principles" (Summer 1990), 28-29. Available at http://www.jstor.org/stable/1191793. Accessed May 11, 2013.

39. AAUP, "Academic Freedom and Tenure, 1923-1932," Bulletin of the American Association of University Professors 18, no. 5 (May 1932): 330-31. Emphasis added.

40. Quoted in Metzger, "1940 Statement of Principles," 28. It is also worth noting that Dewey, in relation to the 1940 Statement and the "Red Scare," was against Communist radicalism. His role in New York City teacher union strife is well documented, if beyond the scope of this paper. See, for example, Andrew Feffer, "The Presence of Democracy: Deweyan Exceptionalism and Communist Teachers in the 1930s," Journal of the History of Ideas 66, no. 1 (January 2005): 79-97. Additionally, Dewey stood firmly behind his otherwise analytic nemesis, Bertrand Russell, when Russell was first contracted by the City University of New York but had the offer rescinded because of perceived radicalism 
on his part. See John Dewey and Horace M. Kallan, The Bertrand Russell Case (New York: The Viking Press, 1941).

41. Ibid., 29.

42. Ibid.

43. Robert B. Sutton, “The Phrase Libertas Philosophandi," Journal of the History of Ideas 14 (1953): 310-16, 310. See also, Benjamin Baez and Deron Boyles, The Politics of Inquiry: Education Research and the "Culture of Science" (New York: SUNY Press, 2009), 167ff.

44. Walter P. Metzger, "Academic Freedom and Scientific Freedom," Daedalus: Journal of the American Academy of Arts and Sciences 107, no. 2 (1978): 93-114, 98.

45. Ibid., 97.

46. AAUP, "Academic Freedom," 88.

47. AAUP, "1940 Statement of Principles on Academic Freedom and Tenure (with 1970 Interpretive Comments)" in Policy Documents \& Reports, 9th ed. (Washington, DC: American Association of University Professors and The Johns Hopkins University Press, 2001), 3-10, 3 .

48. Ibid., 3-4.

49. AAUP, "Academic Freedom," 85.

50. Ibid., 84-85. Asking that universities display the logos of their corporate sponsors sounds excessive, but it differs little from selling the naming rights to any physical structure on a university campus, including research laboratories, to the highest bidder such as the Monsanto Laboratory of the Life Sciences at Washington University in St. Louis.

51. See, for example, Sidney Hook, "Corporate Politics on Campus," Freedom at Issue (September-October, 1970). For a broader treatment of academic freedom, see Sidney Hook, "The Principles and Problems of Academic Freedom," Contemporary Education 58, no. 1 (Fall 1986): 6-12.

52. Sheila Slaughter and Gary Rhoades, Academic Capitalism and the New Economy (Baltimore: The Johns Hopkins University Press, 2004): 306. See also, Richard S. Ruch, Higher Ed, Inc.: The Rise of the For-Profit University (Baltimore: The Johns Hopkins University Press, 2001); Jennifer Washburn, University, Inc.: The Corporate Corruption of Higher Education (New York: Basic Books, 2005); David Kirp, Shakespeare, Einstein, and the Bottom Line: The Marketing of Higher Education (Cambridge: Harvard University Press, 2003); and Roger L. Geiger, Knowledge \& Money: Research Universities and the Paradox of the Marketplace (Stanford: Stanford University Press, 2004).

53. See, for example, https://www.insidehighered.com/news/2013/12/17/colleges -report-job-outcomes-results-are-limited-value. Accessed September 27, 2014.

54. "Background Facts on Contingent Faculty," American Association of University Professors, accessed September 20, 2014, http://www.aaup.org/issues/contingency/background-facts.

55. Raphael Sassower, A Sanctuary of Their Own: Intellectual Refugees in the Academy (Lanham, MD: Rowman and Littlefield, 2000), 34.

56. John Dewey, "Academic Freedom” (1902), $M W$ 2: 62.

57. See Colleen Flaherty, “Grant Quota to Be Paid," Inside Higher Ed (March 10, 2014). Accessed August 17, 2014, https://www.insidehighered.com/news/2014/03/10/columbia -criticized-not-renewing-long-term-professors-over-their-failure-pay. See also Michelle Goldberg, "Columbia University Fired Two Eminent Public Intellectuals. Here's Why It Matters," The Nation (March 12, 2014). Accessed August 17, 2014, http://www.thenation.com /article/178821/shortchanging-mind\#.

58. See Flaherty. 
59. AAUP, “Academic Freedom," 93.

60. For more on the AAUP's confrontations with David Horowitz, see Cary Nelson, No University Is an Island (New York: New York University Press, 2010), 163-96.

61. Dewey, "Academic Freedom," 57.

62. Campus Reform operates its own YouTube channel precisely for this purpose.

63. See Scott Jaschik, “Too Risky for Boulder?” Inside Higher Ed (December 16, 2013). Accessed August 18, 2014, https://www.insidehighered.com/news/2013/12/16/tenured -professor-boulder-says-she-being-forced-out-over-lecture-prostitution.

64. Adler was allegedly given the option to retire or remain at the university only if she agreed to give up teaching the class. She claims she was warned that she risked being fired if future complaints surfaced.

65. William G. Tierney and Vicente M. Lechuga, "Academic Freedom in the 21st Century," Thought and Action (Fall 2005): 11.

66. AAUP, “Academic Freedom," 97.

67. Ibid., 97.

68. In the post-9/11 era, illustrations of purging dissenters include the University of Colorado (Ward Churchill) and University of South Florida (Sam Al-Arian) where these faculty members were, in fact, dismissed because of their views regarding 9/11. A more recent example would be that of Steve Salaita, the Virginia Tech professor who was sent a contractual letter subsequently withdrawn from the University of Illinois.

69. Randolph Bourne, "The War and the Intellectuals" in The Radical Will: Randolph Bourne (Selected Writings: 1911-1918), ed. Olaf Hansen (New York: Urizen Books, 1977): 315.

\section{BiBLIOGRAPHY}

American Association of University Professors. "Academic Freedom." Bulletin of the American Association of University Professors 29, no. 1 (February 1943): 82-101. ___. "Academic Freedom and Tenure, 1923-1932." Bulletin of the American Association of University Professors 18, no. 5 (May 1932): 326-400.

_-_. "Background Facts on Contingent Faculty." Accessed September 20, 2014. http://www.aaup.org/issues/contingency/background-facts.

_-_. "1940 Statement of Principles on Academic Freedom and Tenure (with 1970 Interpretive Comments).” In Policy Documents \& Reports, 9th ed., 3-10. Washington, DC: American Association of University Professors and The Johns Hopkins University Press, 2001.

Baez, Benjamin, and Deron Boyles. The Politics of Inquiry: Education Research and the "Culture of Science." New York: SUNY Press, 2009.

Bourne, Randolph. "Twilight of Idols." In The Radical Will: Randolph Bourne (Selected Writings: 1911-1918), ed. Olaf Hansen. New York: Urizen Books, 1977. -_- "A War Diary." In The Radical Will: Randolph Bourne (Selected Writings: 1911-1918), ed. Olaf Hansen. New York: Urizen Books, 1977.

- - - "The War and the Intellectuals." In The Radical Will: Randolph Bourne (Selected Writings: 1911-1918), ed. Olaf Hansen. New York: Urizen Books, 1977. 
Blum, Howard. Dark Invasion: 1915: Germany's Secret War and the Hunt for the First Terrorist Cell in America. New York: HarperCollins, 2014.

Clark, Christopher. The Sleepwalkers: How Europe Went to War in 1914. New York: HarperCollins, 2012.

Cochran, Molly. “Dewey as International Thinker.” In Molly Cochran, ed., The Cambridge Companion to Dewey. Cambridge: Cambridge University Press, 2010.

Cywar, Alan. "John Dewey in World War I: Patriotism and International Progressivism.” American Quarterly 21, no. 3 (1969): 578-94.

Dewey, John. “Academic Freedom.” In John Dewey: The Middle Works: 1899-1924,

(2) 1902-1903, ed. Jo Ann Boydston. Carbondale: Southern Illinois University Press, 1976.

___. “The Discrediting of Idealism.” The New Republic 20, no. 257 (1919): 285-87.

_-_. German Philosophy and Politics. New York: Henry Holt, 1915.

- - - "Our Educational Ideal in Wartime." In John Dewey: The Middle Works: 1899-1924, (10) 1916-1917, ed. Jo Ann Boydston. Carbondale: Southern Illinois University Press, 1980.

Flaherty, Colleen. “Grant Quota to Be Paid.” Inside Higher Ed (March 10, 2014). Accessed August 17, 2014. https://www.insidehighered.com/news/2014/03/10 /columbia-criticized-not-renewing-long-term-professors-over-their-failure-pay. Garrison, Jim. "Recovery, Reconstruction, and Self-Renewal." In Philosophy of Education 2002, 282-84. Urbana, IL: Philosophy of Education Society, 2003.

Goldberg, Michelle. "Columbia University Fired Two Eminent Public Intellectuals: Here's Why It Matters.” The Nation (March 12, 2014). Accessed August 17, 2014. http://www.thenation.com/article/178821/shortchanging-mind\#.

Geiger, Roger L. Knowledge \& Money: Research Universities and the Paradox of the Marketplace. Stanford, CA: Stanford University Press, 2004.

Gruber, Carol Signer. "Academic Freedom at Columbia University, 1917-1918: The Case of James McKeen Cattell." AAUP Bulletin 58, no. 3 (September 1972): 297-305.

Howlett, Charles F. "John Dewey and the Crusade to Outlaw War." World Affairs 138, no. 4 (Spring, 1976): 336-55.

Jaschik, Scott. “Too Risky for Boulder?” Inside Higher Ed (December 16, 2013). Accessed August 18, 2014. https://www.insidehighered.com/news/2013/12/16 /tenured-professor-boulder-says-she-being-forced-out-over-lecture-prostitution. Kennedy, David M. Over Here: The First World War and American Society. Oxford: Oxford University Press, 1980/2004.

Kirp, David. Shakespeare, Einstein, and the Bottom Line: The Marketing of Higher Education. Cambridge: Harvard University Press, 2003.

Levine, Daniel. "Randolph Bourne, John Dewey, and the Legacy of Liberalism." The Antioch Review 29, no. 2 (Summer 1969): 234-44.

Lovejoy, Arthur O., Edward Capps, and A. A. Young. "Report of Committee on Academic Freedom in Wartime." Bulletin of the American Association of University 
Professors (1915-1955) (4, no. 2/3, February-March 1918): 29-47. Accessed August 20, 2014. http://www.jstor.org/stable/40216871.

Ludlum, Robert P. "Academic Freedom and Tenure: A History." The Antioch Review 10, no. 1 (Spring 1950): 3-34.

Martin, Jay. The Education of John Dewey: A Biography. New York: Columbia University Press, 2002.

Metzger, Walter P. “Academic Freedom and Scientific Freedom.” Daedalus: Journal of the American Academy of Arts and Sciences 107, no. 2 (1978): 93-114.

_-_. "The 1940 Statement of Principles on Academic Freedom and Tenure." Law and Contemporary Problems 53, no. 3 (1990), "Freedom and Tenure in the Academy: The Fiftieth Anniversary of the 1940 Statement of Principles" (Summer): 3-77. Accessed May 11, 2013. http://www.jstor.org/stable/1191793.

- - - "Origins of the Association: An Anniversary Address." AAUP Bulletin 3 (June 1965).

- - - ed. Professors on Guard: The First AAUP Investigations. New York: Arno Press, 1977.

Nelson, Cary. No University Is an Island. New York: New York University Press, 2010. Pollitt, Daniel H., and Jordan E. Kurland. "Entering the Academic Freedom Arena Running: The AAUP's First Year." Academe 84, no. 4 (July-August 1998): 45-52.

Ruch, Richard S. Higher Ed, Inc.: The Rise of the For-Profit University. Baltimore: The Johns Hopkins University Press, 2001.

Ryan, Alan. John Dewey and the High Tide of American Liberalism. New York: W. W. Norton, 1995.

Samuels, Warren J. “The Firing of E. A. Ross from Stanford University: Injustice Compounded by Deception?" The Journal of Economic Education 22, no. 2 (Spring 1991): 183-90.

Sassower, Raphael. A Sanctuary of Their Own: Intellectual Refugees in the Academy. Lanham, MD: Rowman and Littlefield, 2000.

Slaughter, Sheila, and Gary Rhoades. Academic Capitalism and the New Economy. Baltimore: The Johns Hopkins University Press, 2004.

Stone, Lynda. "Dewey's Contribution to an American Hubris: Philosophy of Democracy, Education, and War." Philosophy of Education 2002, 274-81. Urbana: Philosophy of Education Society, 2003.

Summerscales, William. Affirmation and Dissent: Columbia's Response to the Crisis of World War I. New York: Teachers College Press, 1970.

Sutton, Robert B. “The Phrase Libertas Philosophandi." Journal of the History of Ideas 14 (1953): 310-16.

Tiede, Hans-Joerg. “To Make Collective Action Possible': The Founding of the AAUP.” Journal of Academic Freedom 5 (2014): 1-29.

Tierney, William G., and Vincente M. Lechuga. "Academic Freedom in the 21st Century." Thought \& Action (Fall 2005): 7-22. 
In Defense of Academic Freedom and Faculty Governance 43

Veblen, Thorstein. The Higher Learning in America. New York: B. W. Huebsch, 1918. Washburn, Jennifer. University, Inc.: The Corporate Corruption of Higher Education. New York: Basic Books, 2005.

Westbrook, Robert B. John Dewey and American Democracy, Ithaca: Cornell University Press, 1991.

Wiebe, Robert H. The Search for Order, 1877-1920. New York: Hill and Wang, 1967.

Nicholas J. Eastman is a graduate student at Georgia State University. Email: neastman1 @student.gsu.edu.

Deron Boyles is a professor of philosophy of education in the Department of Educational Policy Studies at Georgia State University. Email: dboyles@gsu.edu. 
